\title{
Front Matter: Volume 8069
}

, "Front Matter: Volume 8069," Proc. SPIE 8069, Integrated Photonics: Materials, Devices, and Applications, 806901 (14 June 2011); doi: $10.1117 / 12.901400$

SPIE. Event: SPIE Microtechnologies, 2011, Prague, Czech Republic 


\title{
PROCEEDINGS OF SPIE
}

\section{Integrated Photonics: Materials, Devices, and Applications}

\author{
Ali Serpengüzel \\ Giancarlo C. Righini \\ Alfred Leipertz \\ Editors
}

18-20 April 2011

Prague, Czech Republic

Sponsored and Published by

SPIE 
The papers included in this volume were part of the technical conference cited on the cover and title page. Papers were selected and subject to review by the editors and conference program committee. Some conference presentations may not be available for publication. The papers published in these proceedings reflect the work and thoughts of the authors and are published herein as submitted. The publisher is not responsible for the validity of the information or for any outcomes resulting from reliance thereon.

Please use the following format to cite material from this book:

Author(s), "Title of Paper," in Integrated Photonics: Materials, Devices, and Applications, edited by Ali Serpengüzel, Giancarlo C. Righini, Alfred Leipertz, Proceedings of SPIE Vol. 8069 (SPIE, Bellingham, WA, 2011) Article CID Number.

ISSN 0277-786X

ISBN 9780819486585

Published by

SPIE

P.O. Box 10, Bellingham, Washington 98227-0010 USA

Telephone +1 3606763290 (Pacific Time) · Fax +1 3606471445

SPIE.org

Copyright (C) 2011, Society of Photo-Optical Instrumentation Engineers

Copying of material in this book for internal or personal use, or for the internal or personal use of specific clients, beyond the fair use provisions granted by the U.S. Copyright Law is authorized by SPIE subject to payment of copying fees. The Transactional Reporting Service base fee for this volume is $\$ 18.00$ per article (or portion thereof), which should be paid directly to the Copyright Clearance Center (CCC), 222 Rosewood Drive, Danvers, MA 01923. Payment may also be made electronically through CCC Online at copyright.com. Other copying for republication, resale, advertising or promotion, or any form of systematic or multiple reproduction of any material in this book is prohibited except with permission in writing from the publisher. The CCC fee code is 0277-786X/11/ \$18.00.

Printed in the United States of America.

Publication of record for individual papers is online in the SPIE Digital Library.

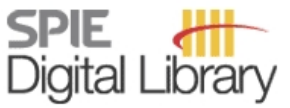

SPIEDigitalLibrary.org

Paper Numbering: Proceedings of SPIE follow an e-First publication model, with papers published first online and then in print and on CD-ROM. Papers are published as they are submitted and meet publication criteria. A unique, consistent, permanent citation identifier (CID) number is assigned to each article at the time of the first publication. Utilization of CIDs allows articles to be fully citable as soon as they are published online, and connects the same identifier to all online, print, and electronic versions of the publication. SPIE uses a six-digit CID article numbering system in which:

- The first four digits correspond to the SPIE volume number.

- The last two digits indicate publication order within the volume using a Base 36 numbering system employing both numerals and letters. These two-number sets start with $00,01,02,03,04$, $05,06,07,08,09,0 A, 0 B \ldots 0 Z$, followed by 10-1Z, 20-2Z, etc.

The CID number appears on each page of the manuscript. The complete citation is used on the first page, and an abbreviated version on subsequent pages. Numbers in the index correspond to the last two digits of the six-digit CID number. 


\section{Contents}

vii Conference Committee
ix Introduction

SESSION 1 VLSI PHOTONICS

806904 Demonstration of ITU channel interleaver in SOI with large cross section single mode waveguides [8069-03]

G. R. Bhatt, B. K. Das, Indian Institute of Technology Madras (India)

806905 Widely tunable single-mode high power quantum cascade lasers (Invited Paper) [8069-10] M. Razehi, B. Gökden, S. Tsao, A. Haddadi, N. Bandyopadhyay, S. Slivken, Northwestern Univ. (United States)

\section{SESSION 2 DISCRETE PHOTONIC DEVICES}

806906 Polarized optical injection in long-wavelength vertical-cavity surface emitting lasers (Invited Paper) [8069-05]

A. Hurtado, K. Schires, N. Khan, R. Al-Seyab, I. D. Henning, M. J. Adams, Univ. of Essex (United Kingdom)

806907 Development of a high-speed wideband frequency tunable infrared laser source for real time wind turbine array sensing applications [8069-06]

P. Mitchell, Oclaro, Inc. (United Kingdom) and Univ. of Bolton (United Kingdom); A. Janssen,

B. Partov Poor, Oclaro, Inc. (United Kingdom)

806908 UV diamond power switches [8069-07]

P. Calvani, M. Girolami, G. Ricciotti, G. Conte, Univ. degli Studi di Roma Tre (Italy)

8069 OA Thermal behavior of waveguide gratings [8069-09]

M. R. Saleem, Univ. of Eastern Finland (Finland) and National Univ. of Sciences and Technology (Pakistan); M. B. Khan, Z. M. Khan, National Univ. of Sciences and Technology (Pakistan); P. A. Stenberg, Univ. of Eastern Finland (Finland); T. Alasaarela, Aalto Univ.

(Finland); S. Honkanen, Univ. of Eastern Finland (Finland) and Aalto Univ. (Finland); B. Bai, Univ. of Eastern Finland (Finland) and Tsinghua Univ. (China); J. Turunen, P. Vahimaa, Univ. of Eastern Finland (Finland)

\section{SESSION 3 QUANTUM PHOTONIC DEVICES AND MATERIALS}

8069 OB Fabrication and evaluation of photorefractive waveguide in LiNbO $:$ :Fe [8069-41]

N. Tarjányi, D. Káčik, Univ. of Žilina (Slovakia)

8069 OD Dynamic response of CVD monocrystalline diamond to low-energy x-ray beam [8069-12] D. M. Trucchi, CNR-IMIP (Italy); P. Allegrini, Univ. degli Studi di Roma Tre (Italy); S. Spadaro,

G. Conte, Univ. degli Studi di Roma Tre (Italy) and INFN-Roma Tre (Italy) 
8069 OE Quantum state transfer among crystallographic groups of N-V centers in diamond (Invited Paper) [8069-13]

Ö. E. Müstecaplioğlu, Koç Univ. (Turkey)

SESSION 4 PHOTONIC ATOM AND CRYSTALS

8069 0G Super-directive beam from metamaterials [8069-15]

V. Mocella, P. Dardano, I. Rendina, CNR-IMM (Italy); S. Cabrini, Lawrence Berkeley National Lab. (United States)

8069 Ol Hybrid colloidal crystal for photonic application (Invited Paper) [8069-17]

A. Chiappini, C. Armellini, CNR-IFN, CSMFO Lab. (Italy); N. Bazzanella, Univ. degli Studi di Trento (Italy); A. Carpentiero, CNR-IFN, CSMFO Lab. (Italy); G. C. Righini, CNR-IFAC (Italy); M. Ferrari, CNR-IFN, CSMFO Lab. (Italy)

\section{SESSION $5 \quad$ PHOTONIC ATOM AND WAVEGUIDES}

8069 OK Development and optical characterization of vertical tapers in SiON waveguides using gray-scale lithography [8069-19]

B. Han, Univ. degli Studi di Trento (Italy) and Fondazione Bruno Kessler (Italy); E. Rigo, Univ. degli Studi di Trento (Italy) and Univ. di Modena e Reggio Emilia (Italy); R. Guider, S. Larcheri, Univ. degli Studi di Trento (Italy); G. Nunzi Conti, CNR-IFAC, MDF Lab. (Italy);

M. R. Vanacharla, Univ. degli Studi di Trento (Italy); A. Chiasera, M. Ferrari, CNR-IFN, CSMFO Lab. (Italy); L. Pavesi, Univ. degli Studi di Trento (Italy); G. Pucker, Fondazione Bruno Kessler (Italy); G. C. Righini, CNR-IFAC, MDF Lab. (Italy); M. Ghulinyan, Fondazione Bruno Kessler (Italy)

8069 OL Electro-optical modulation with silicon microspheres in liquid crystal [8069-20]

H. Yilmaz, A. Serpengüzel, Koç Univ. (Turkey)

\section{SESSION $6 \quad$ MATERIALS}

8069 ON Down-converter based on rare earth doped fluoride glass to improve Si-based solar cell efficiency [8069-23]

G. Alombert Goget, D. Ristic, A. Chiasera, S. Varas, M. Ferrari, CNR-IFN, CSMFO Lab. (Italy); G. C. Righini, CNR-IFAC, MDF Lab. (Italy); B. Dieudonné, B. Boulard, LdOF Lab., CNRS, Univ. du Maine (France)

8069 OP Characterisation of thin LPCVD silicon-rich oxide films [8069-25]

D. Ristić, CNR-IFN, CSMFO Lab. (Italy) and Ruđer Bošković Institute (Croatia); M. Ivanda, M. Marciuš, Ruđer Bošković Institute (Croatia); V. Holý, Charles Univ. in Prague (Czech Republic); Z. Siketić, I. Bogdanović-Radović, Ruđer Bošković Institute (Croatia); O. Gamulin, Univ. of Zagreb (Croatia); K. Furić, M. Ristić, S. Musić, M. Buljan, Ruđer Bošković Institute (Croatia); M. Ferrari, A. Chiasera, A. Chiappini, CNR-IFN, CSMFO Lab. (Italy); G. C. Righini, CNR-IFAC, MDF Lab (Italy) 
8069 OS PECVD deposition and characterization of silicon oxynitride for optical applications [8069-28]

A. B. Alamin Dow, K. Leong, A. B. Gougam, H. Alizadeh, N. P. Kherani, Univ. of Toronto

(Canada)

\section{SESSION 7 FABRICATION}

8069 OU UV-imprinting of single-mode polymeric waveguides [8069-30]

J. Hiltunen, VTT Technical Research Ctr. of Finland (Finland); M. Wang, Univ. of Oulu (Finland); M. Hiltunen, VTT Technical Research Ctr. of Finland (Finland); J. Puustinen, J. Lappalainen, Univ. of Oulu (Finland); S. Pearce, M. Charlton, Univ. of Southampton (United Kingdom); P. Karioja, VTT Technical Research Ctr. of Finland (Finland)

8069 OV Assembly of a photonic wavelength-division multiplexing device using laser-based soldering [8069-31]

T. Burkhardt, Fraunhofer-Institut für Angewandte Optik und Feinmechanik (Germany) and Friedrich-Schiller-Univ. (Germany); M. Hornaff, A. Kamm, Fraunhofer-Institut für Angewandte Optik und Feinmechanik (Germany); M. Rütz, T. Possner, Grintech GmbH (Germany); E. Beckert, R. Eberhardt, Fraunhofer-Institut für Angewandte Optik und Feinmechanik (Germany); A. Tünnermann, Fraunhofer-Institut für Angewandte Optik und Feinmechanik (Germany) and Friedrich-Schiller-Univ. (Germany)

8069 OW Process optimization to design titanium-indiffused lithium niobate channel waveguides for Mach-Zehnder interferometer switch [8069-33]

G. Singh, S. Gupta, S. Bothra, V. Janyani, R. P. Yadav, Malaviya National Institute of Technology (India)

\section{SESSION 8 APPLICATIONS}

8069 OY Gas-phase diagnostic by time-resolved rotational coherent anti-Stokes Raman spectroscopy (Invited Paper) [8069-35]

T. Seeger, Univ. Siegen (Germany) and Friedrich-Alexander-Univ. Erlangen-Nürnberg

(Germany); A. Leipertz, Friedrich-Alexander-Univ. Erlangen-Nürnberg (Germany)

$80690 Z$ A speckle-based CMOS sensor array for arbitrary surface movement detection [8069-36] C. Wang, S. Tanner, P.-A. Farine, Ecole Polytechnique Fédérale de Lausanne (Switzerland)

806910 Polarization gratings allow for real-time and artifact-free circular dichroism measurements [8069-37]

P. Pagliusi, Univ. of Calabria (Italy) and CNR-IPCF (Italy); E. Lepera, C. Provenzano, Univ. of Calabria (Italy); A. Mazzulla, CNR-IPCF (Italy); G. Cipparrone, Univ. of Calabria (Italy) and CNR-IPCF (Italy) 
806914 Optical characteristics of triangular microresonator with long evanescent field on the total internal reflection mirror [8069-42]

D. G. Kim, S. H. Kim, H. C. Ki, W.-G. Jang, D.-K. Lee, H. J. Kim, T. U. Kim, H. J. Kim, Korea Photonics Technology Institute (Korea, Republic of); G.-Y. Oh, Y. W. Choi, Chung-Ang Univ. (Korea, Republic of)

806917 Tuning of optical resonances of a microsphere with liquid crystal [8069-45]

H. Yilmaz, Koç Univ. (Turkey); M. S. Tamer, O. Gürlü, Istanbul Technical Univ. (Turkey);

A. Serpengüzel, Koç Univ. (Turkey)

\section{SESSION 9 VLSI PHOTONICS II}

806919 Novel optical interconnect devices and coupling methods applying self-written waveguide technology (Invited Paper) [8069-04]

K. Nakama, O. Mikami, Tokai Univ. (Japan)

Author Index 


\title{
Conference Committee
}

\author{
Symposium Chair
}

Thomas Becker, EADS Innovation Works (Germany)

Symposium Cochairs

José Feliciano López, Universidad de Las Palmas de Gran Canaria (Spain)

Gerhard Krötz, Hochschule Kempten (Germany)

Symposium Local Chair

Cestmír Ondrůšek, Technical University of Brno (Czech Republic)

Conference Chairs

Ali Serpengüzel, Koç University (Turkey)

Giancarlo C. Righini, Istituto di Fisica Applicata Nello Carrara (Italy)

Alfred Leipertz, Friedrich-Alexander-Universität Erlangen-Nürnberg

(Germany)

\section{Program Committee}

Michael J. Adams, University of Essex (United Kingdom)

Richard M. De La Rue, University of Glasgow (United Kingdom)

Patrice Féron, Ecole Nationale Supérieure des Sciences Appliquées et de Technologie (France)

Maurizio Ferrari, Istituto di Fotonica e Nanotecnologie (Italy)

Gershon Kurizki, Weizmann Institute of Science (Israel)

El-Hang Lee, Inha University (Korea, Republic of)

Eric D. Mazur, Harvard University (United States)

Ekmel Özbay, Bilkent University (Turkey)

Lorenzo Pavesi, Università degli Studi di Trento (Italy)

Andrew W. Poon, Hong Kong University of Science and Technology (Hong Kong, China)

Valerio Pruneri, ICFO-Instituto de Ciencias Fotónicas (Spain)

Manijeh Razeghi, Northwestern University (United States)

Ivo Rendina, Istituto per la Microelettronica e Microsistemi (Italy)

Niyazi S. Sariciftci, Johannes Kepler University Linz (Austria)

Gustav Schweiger, Ruhr-Universität Bochum (Germany)

Hakan E. Tureci, ETH Zurich (Switzerland) 


\section{Session Chairs}

1 VLSI Photonics

Giancarlo C. Righini, Istituto di Fisica Applicata Nello Carrara (Italy)

2 Discrete Photonic Devices

El-Hang Lee, Inha University (Korea, Republic of)

3 Quantum Photonic Devices and Materials

Antonio Hurtado, University of Essex (United Kingdom)

$4 \quad$ Photonic Atom and Crystals

Özgür E. Müstecaplioglu, Koç University (Turkey)

$5 \quad$ Photonic Atom and Waveguides

Mher Ghulinyan, Fondazione Bruno Kessler (Italy)

6 Materials

Patrice Féron, Ecole Nationale Supérieure des Sciences Appliquées et de Technologie (France)

7 Fabrication

Özgür E. Müstecaplioglu, Koç University (Turkey)

8 Applications

Alfred Leipertz, Friedrich-Alexander-Universität Erlangen-Nürnberg (Germany) 


\section{Introduction}

Optical science and photonics engineering are developing at a faster pace. The optoelectronic and photonic engineer of the 21st century will make use of the tools available to design ever improved photonic devices and systems, whereas the optical and photonic scientist of the 21st century will be busy supplying novel materials, fabrication methods, and applications. Beginning with the new millennium, countries are officially including optics and photonics in their research and development plans and programs to cover application fields from automotive and home lighting to information and communications technologies, from life sciences and health to multidimensional displays, from remote sensing to nondestructive diagnostics, and from material processing to renewable energy. More and more academic degree programs are being offered in optical sciences and photonics engineering all over the world. Soon, this novel discipline

will grow out of the more conventional science and engineering departments and establish itself as the discipline of the 21 st century.

The scope of this conference on integrated photonics materials, devices, and applications has been to bring together optical scientists and photonics engineers who work on the different aspects of this fascinating science and technology in academia, industry, government laboratories, and research centers throughout the planet. The aim was to provide an interdisciplinary update and review of innovations in integrated photonic materials, devices, and applications, as well as theoretical, experimental, and numerical tools that support these innovations. The conference included topics such as very large scale integrated (VLSI) photonics, discrete photonic devices, quantum photonic devices and materials, photonic atoms and crystals, photonic atoms and waveguides, novel photonic materials, fabrication methods, and applications.

Integrated photonics comes about with the VLSI of photonics based on microand nanodevices and waveguides. Discrete photonic devices are to be assembled on optical printed circuit boards (PCBs). Quantum photonic structures are investigated for novel application areas as well as for contribution to the fundamental science. Ordered photonic atoms leading to photonic crystals, and disordered ones leading to photonic glasses, are fascinating. Novel materials, fabrication techniques, and applications are abundant. 
Although this volume includes a fraction of our ever shrinking planet's research and development efforts in the vast field of integrated photonics, we hope that these papers by world renowned experts pave the path for all of us towards the upcoming photonics integration.

\section{Ali Serpengüzel \\ Giancarlo C. Righini Alfred Leipertz}

